Volume 2 Issue 1, Januari-Juni 2021: pp. 31-44.

Faculty of Law, Universitas Lampung, Bandar Lampung, Indonesia. http://jurnal.fh.unila.ac.id/index.php/ip

P-ISSN: 2723-2638 E-ISSN: 2745-9314

\title{
The Legal Position Of Electronic Medical Recording As An Evidence At The Court
}

\author{
Dewi Retno Wulandari \\ dwi.retnowulandari@yahoo.co.id \\ RSUD Jendral Ahmad Yani Metro
}

Submitted: 7 January 2021; Reviewed: 25 January 2021; Accepted: 18 February 2021

\section{Article's Information}

Abstract

Key Word: Electronic; medical;
records; evidence.

DOI:

https://doi.org/10.25041/ip.v2.i1.2209
This research aimed to analyze the position of electronic medical records and as evidence in court. The research method uses a normative juridical approach. To obtain an overview of electronic medical records as evidence in court, the legal materials collected are qualitative data. Any electronic evidence can be used as evidence if it meets formal and material requirements, as regulated in Article 5 paragraph (4) of Law Number 11 of 2008 concerning Electronic Information and Transactions (ITE Law). Electronic medical records have an essential role in health services and law enforcement efforts as evidence. Based on this, the main problem is the position of electronic medical records as valid evidence in court. The results show that the position of electronic medical records as evidence in court can be valid evidence following Article 184 of the Criminal Procedure Code (KUHAP), The Ministry of Health Regulation 269/2008 Articles 5 and 1, Article 51 of Government Regulation No. 71 Years. As evidence, electronic medical records do not have binding evidentiary power but rather have independent evidentiary value, namely, proof determined by the judge's conviction without being limited by law. 


\section{A. Introduction}

The medical record records the patient's condition from the time the patient registers until the patient has been served. The obligation to make medical records is stipulated in Law Number 29 of 2004 concerning Medical Practice. As technology advances, the use of medical records has begun to shift from conventional (paper-based) to digital, both in partial and full form. Until now, many hospitals have used electronic medical records. In addition to data that is easy to find, it also saves file storage space. However, technical instructions for using electronic medical records have not been regulated in various laws and regulations. Hospitals only use the ITE Law as the basis for implementing electronic medical records. Ministry of Health Regulation 269 of 2008 concerning Medical Records is regulated if medical records can be conventional or electronic. This means that de jure (law) the regulation has revealed that electronic medical records can be run.

Hospital is an institution that is carrying out its duties and functions is different compared to other institutions. So, special rules are needed that can regulate all activities in the hospital work unit. ${ }^{1}$ Hospitals must have hospital bylaws that regulate internal policies based on applicable laws. The implementation of electronic medical records can be arranged in hospital bylaws and medical staff bylaws. Regulation of the Minister of Health (Permenkes) Number 82 of 2013 concerning Hospital Management Information Systems or Sistem Informasi Manajemen Rumah Sakit (SIMRS) regulates that each hospital must hold SIMRS. Electronic medical records are part of SIMRS as an administrative function, one of the priorities in implementing SIMRS. The question is whether this regulation can be one of the bases for hospitals to organize electronic medical records because SIMRS does not regulate in more detail the implementation and implementation of electronic medical records.

The ITE Law Number 19 of 2016 is one of the hopes of making a legal basis for the use of electronic transactions. However, the regulation does not regulate how the issue of electronic medical records. The ITE Law only regulates electronic transactions and does not regulate medical record issues because medical records are very complicated when formed in electronic (digital) format. Article 184 of the Criminal Procedure Code states that in addition to serving as administrative evidence, medical records can also be used as evidence in court, as a basis for patient financing, as research documents, as well as documentary evidence of services received by patients. As evidence, the medical record is a vital archive because all service actions will be recorded. This means that with various service problems at the hospital, the implementation of electronic medical records with internal policy regulations can be valid evidence in court if there is a medical dispute. As a medicolegal aspect, the historical condition of patient care contained in the medical record is clear evidence of the actions taken to the patient. ${ }^{2}$

Medical records are conventional versus electronic documents following the meaning of electronic documents according to the ITE Law. Electronic medical records are also electronic information made by caregivers based on the patient's condition, which is forwarded and sent to another section for further consultation and examination and received and stored in digital form and can be viewed at any time if needed. Each department has special access to patient secrets. With the use of information technology, the acceptance of electronic data has become

\footnotetext{
${ }^{1}$ Lucia Murniati, Endang Wahyati Y, and Siswo Putranto Santoso, "IMPLEMENTASI HOSPITAL BYLAWS DI RUMAH SAKIT SANTO ANTONIO BATURAJA SETELAH BERLAKUNYA PERMENKES NOMOR: 755/MenKes/Per/IV/2011 TENTANG PENYELENGGARAAN KOMITE MEDIK DI RUMAH SAKIT," SOEPRA 2, no. 2 (January 10, 2017): 143, https://doi.org/10.24167/shk.v2i2.817.

${ }^{2}$ Nynda Fatmawati Octarina et al., "Tinjauan Terhadap UU ITE Untuk Penerapan Rekam Medis Berbasis Online Pada Penduduk Muslim Di Indonesia,” At-Tahdzib: Jurnal Studi Islam Dan Muamalah 5, no. 2 (2017): 78-94, http://ejournal.kopertais4.or.id/mataraman/index.php/tahdzib/article/view/3253.
} 
an exciting theme. In the provisions of civil procedural law, facts and legal certainty in the plaintiff's case, evidence, and evidence are significant matters. When no provisions regulating evidence are found, law enforcement officials will make it challenging to enforce civil matters. Proving a case is an attempt to convince a judge about the truth exposed with the help of evidence. In order to prevent actions that violate the law, law enforcement officials benefit from the ITE Law. ${ }^{3}$ This provides a legal basis regarding the legality of electronic evidence and the formal and material requirements for electronic evidence to be accepted in court. Article 5 paragraph (1) of the ITE Law stipulates that electronic information and/or electronic documents and/or their printouts are the result of valid evidence. What is meant by electronic information is one or a set of electronic data, including but not limited to writing, voice, images, maps, designs, photographs, electronic data, electronic mail, telegram, telex, telecopy or the like, letters, signs, numbers, access codes, processed symbols, or perforations that have meaning or can be understood by those who are able to understand them. Electronic evidence is obtained from electronic information and electronic documents, and if it is printed it will become documentary evidence.

The position of the actual electronic medical record is that it can be used as authentic evidence in court in the event of a medical dispute. Therefore, the authors are interested in examining the position of electronic medical records as evidence in court. The legal issue in this research is when electronic medical records can be used in hospitals, and there is no legal basis yet, is it legal if the results of the electronic medical records are used as evidence in court when there is a medical dispute.

\section{B. Discussion}

\section{Obligation to Organize Medical Records}

Medical records record the patient's disease history from the patient registering until the patient is declared home. ${ }^{4}$ This data is fundamental and confidential, so every health service practice must make medical records at hospitals, health centers, clinics, and independent health practices. It can be interpreted that a medical record is an obligation that must be fulfilled by every medical service, be it a clinic and/or hospital. The obligation to make medical records is stipulated in Article 46 of Law Number 29 of 2004 concerning Medical Practice, which is that every hospital is obliged to organize medical records. Provisions for carrying out medical records are also contained in the Midwifery Law Number 4 of 2019 Article 61. Namely, midwifery care must be documented according to standards. The Nursing Law Number 38 of 2014 Article 37 also regulates that in carrying out nursing practice, it is mandatory to document nursing care which is also described in Article 51 of the Minister of Health Number 26 of 2019 concerning the Implementation Regulations of the Nursing Law, in addition to recording and reporting, it is also mandatory to keep records of nursing care.

Following existing regulations. Health service facilities and medical practices must maintain medical records. However, Article 70 of the Health Workers Law Number 36 of 2014 also regulates that every time they carry out the individual practice, health workers must make medical records. Based on the various laws and regulations above, medical records are vital to document patients' services. Even though they contain patient data, the medical record document belongs to the health service provider. The confidentiality of the patient's medical

\footnotetext{
3 Johan Wahyudi, "DOKUMEN ELEKTRONIK SEBAGAI ALAT BUKTI PADA PEMBUKTIAN DI PENGADILAN," Perspektif 17, no. 2 (May 27, 2012): 118-26, http://jurnalperspektif.org/index.php/perspektif/article/view/101.

${ }^{4}$ PB IDI Decree No.315 / PB / A.4 / 88 number 1 (In this decree, there is a coherent explanation of the Medical Record that guides doctors, clinics, and hospitals in health services)
} 
information must be kept because it is a medical secret. The patient is only entitled to the contents of the medical record. The regulations governing mandatory preservation of medical secrets are Government Regulation Number 10 of 1966 Concerning Mandatory Keeping of Medical Secrets Articles 1 and 2, which are renewed by The Ministry of Health Regulation Number 36 of 2012 concerning Medical Secrets, in general, regulating the obligation to keep confidential medical record information contained and regulated explicitly in regulations. Minister of health and legislation of each profession.

Decisions taken by patients in services that have been given for their interests make patients independent legal subjects. In this condition, it is not necessary to protect the patient's interests in a weak position. This condition causes the desire to seek problems regarding patients' rights when dealing with health workers, especially doctors. ${ }^{5}$ Meanwhile, a patient comes to health service to consult directly or indirectly with a doctor or dentist about the necessary health problems.

\section{Electronic Medical Records}

Electronic medical records arise when patient data in the form of paper is transferred to an existing program on a computer. Electronic medical records are data about patient records regarding examinations, treatments, actions, and other services. Some hospitals have used the method of digitizing medical records to reduce paper use and provide storage space. However, not many have used electronic medical records in full, and costs and programs must be adapted to hospital conditions changing the human resources' behavior. However, if the electronic medical record is already running, there are many benefits for the hospital. Article 2 The Ministry of Health Regulation 269 of 2008 concerning Medical Records stipulates that the implementation of medical records must be made in complete and clear writing or electronically. Implicitly the implementation of medical records is permitted, but there are no regulations regarding technical instructions for the management of medical records using digital technology. ${ }^{6}$

Changes in the medical record model from conventional to electronic are starting to be used by some hospitals because of the ease with which this system is obtained. The use of medical records, both paper-based and electronic, as an administrative function, evidence (legal), financing patient services (financial), to research documents (research) as evidence of documentation of services to patients. As evidence, the medical record is an essential document because all service actions that have been performed are recorded in it. Legal obligations in terms of privacy and data security can be seen indirectly in the provisions of articles 30 to 33 and article 35 of the ITE Law, which regulates prohibited acts. In this case, the ITE Law strictly prohibits anyone from using electronic systems to gain unauthorized access, which causes illegal actions against other people's data to obtain information by manipulating, changing, or removing by illegally accessing electronic systems' security.

Legal obligations in terms of privacy and data security can be seen indirectly in the provisions of articles 30 to 33 and article 35 of the ITE Law, which regulates prohibited acts. In this case, the ITE Law strictly prohibits anyone from using electronic systems to gain unauthorized access, which causes illegal actions against other people's data to obtain information by manipulating, changing, or removing by illegally accessing electronic systems' security. ${ }^{7}$ In electronic medical records, those who have the authority are Professional Caregivers or Profesional Pemberi Asuhan (PPA), including doctors, pharmacists, dietitians, and paramedics. Compound information in medical records includes patient social data to data

\footnotetext{
${ }^{5}$ Zaeni Asyhadie, Aspek-Aspek Hukum Kesehatan Di Indonesia, Rajawali Pers, 2017, Depok. Pg. 70-71.

${ }^{6}$ Nuryati, 21 August 2019, Aspek hukum Rekam Medis Elektronik, https://mik.sv.ugm.ac.id/2019/08/21/aspekhukum-rekam-medis-elekronik/, accessed on 14 June 2020.

${ }^{7}$ Boy S. Sabarguna, 2008, Rekam Medis Terkomputerisasi, (Jakarta: UI Press), pg. 22
} 
that can be misused, including diagnosis, treatment information, and supporting tests. From this information, there are particular needs from other organizations, including public health services and other third parties, for example, insurance companies and courts. The court is a legal institution if there is an order to obtain data. According to the regulations, the release of medical records from the hospital is only based on the court's orders or requests. ${ }^{8}$

Patients' medical records are confidential. Those who are obliged to maintain these documents are not only PPA, administrative staff, and practicing students are also obliged to maintain the confidentiality of medical records. The regulation of the protection of personal data in an electronic system can become a reference for implementing electronic medical records. Before the electronic system is used, registration must be carried out by the service provider agency or agency. Whereas for non-public services, it is not mandatory but can register. In terms of governance, electronic system administrators must ensure that each element can run systematically so that the electronic system functions as it should.

About registration, before the electronic system is used, registration must be carried out by the agency or administrative body. Registration of electronic transactions used by companies is also confirmed by the Ministry of Communication and Information Technology or Kementerian Komunikasi dan Informatika (Kemkominfo). Hospitals that maintain electronic medical records are required to register the electronic system used by the service. Whereas for non-public services, it is not mandatory but can register. In terms of governance, electronic system administrators must ensure that each element can run systematically so that the electronic system functions as it should. ${ }^{9}$ Electronic certification provider that is certified and registered at the Ministry of Communication and Information is PT. Solusi Net Internusa, PT. Privy Identitas Digital, Perusahaan Umum Percetakan Uang Republik Indonesia, PT. Indonesia Digital Identity (VIDA), Balai Sertifikasi Elektronik Badan Siber dan Sandi Negara (BSSN), Badan Pengkajian dan Penerapan Teknologi or Agency for the Assessment and Application of Technology. ${ }^{10}$

In organizing electronic medical records, health service facilities must pay attention to several aspects, among others.

1. Medical Records Confidentiality

The implementation of electronic medical records must pay attention to the confidentiality aspects of medical records, one of which is the protection of privacy related to the existence of a secure system. The hospital must set the internal and external access rights to regulate electronic medical records' security system.

2. Procedures for correcting medical records in case of recording errors.

Medical records in any format are legal documents. This means the document cannot be deleted or made inaccessible part of the active patient medical record. If regulations are made for correcting errors, the original electronic documents (including errors) should be kept and accessible. ${ }^{11}$ Prevention of misuse by unauthorized persons, network security, is an essential element to monitor unauthorized access to network resources. In this case, the data can only be accessed by authorized parties and

\footnotetext{
${ }^{8}$ Sudjana Sudjana, “Aspek Hukum Rekam Medis Atau Rekam Medis Elektronik Sebagai Alat Bukti Dalam Transaksi Teurapetik," Veritas et Justitia 3, no. 2 (December 26, 2017): 359-83, https://doi.org/10.25123/vej.2685.

${ }^{9}$ Regulation of the Minister of Communication and Information Technology Number 36 of 2014 concerning Registration Procedures for Electronic System Operators and Regulation of the Minister of Communication and Information Technology Number 10 of 2015 concerning Registration Procedures for Electronic Systems of State Administering Agencies

${ }^{10}$ https://tte.kominfo.go.id/listPSrE/

${ }^{11}$ Retention and Destruction of Health Information, August https://library.ahima.org/PB/RetentionDestruction\#.X2N0i2gzbIX di accessed on 1 September 2020

2011,
} 
application security, where each user can be uniquely identified. It will be easily recognized if an unauthorized user changes the data through a username or password.

3. Storage and disposal of medical records

For electronic medical record data storage, the hospital can make a policy on storing electronic documents based on the regulations on electronic documents. To destroy electronic medical record data, the hospital can refer to the regulations regarding the record retention schedule within the Ministry of Health or have a policy on destruction. Electronic medical record data. Each data has a different use-value, including administrative, financial, educational, and research values and historical values. The benefits of data as a memory center, a source of information, and a reference for management in making decisions.

4. Authentication, that is, every record in the medical record must be given the name, signature, time, and date of services performed by the Care Professional or Profesional Pemberi Asuhan (PPA).

Essential aspects in the administration of medical records, both conventional versus electronic, are authentication and confidentiality. The authentication in question is the identification of the signature of the medical record-maker. In conventional medical records, direct signatures can be affixed to the patient's medical record, while for electronic medical records, the signature required can be digital or electronic.

From a legal perspective, the ITE Law is related to its legal basis, electronic medical records as electronic documents or electronic transactions under Article 12 of the ITE Law, which has organized electronic signatures. When the medical records are run, how to ensure that when digitizing the data the same as the printed ones, there is no possibility of modification and securing it. When something is electronic, it cannot become evidence in court. According to Rinaldy ${ }^{12}$ Several electronic documents can be used as evidence in court, including a certified electronic signature. Electronic signatures include both certified and noncertified signatures. Electronic certificates issued by electronic certification operators have legal power and consequences. Electronic signatures that are not certified are made without using the Penyelenggara Sertifikasi Elektronik Indonesia (PSRE) services. Signature serves to identify and distinguish documents created by one person from others. ${ }^{13}$

Electronic signature describes a customized signing identity based on electronic signature creation data where the electronic signature creation data is uniquely created, which only selects on a signing. ${ }^{14}$ Essential aspects in the implementation of medical records, both conventional and electronic, are authentication and confidentiality. The authentication in question is the identification of the signature of the medical record-maker. In conventional medical records, direct signatures can be affixed to the patient's medical record, whereas in electronic medical records, the signature can be a digital signature or an electronic signature. Signatures that are not certified include scanned signatures; signatures entered into electronic devices, fingerprints, retin scans, and pins or passwords owned by each user to identify the electronic document maker's authentication. Meanwhile, a certified signature is a digital signature with cryptography.

\footnotetext{
${ }^{12}$ Head of the Electronic Certification Agency for the National Cyber and Crypto Agency (Interview, 14 May 2020)

13 Enju Juanda, "KEKUATAN ALAT BUKTI DALAM PERKARA PERDATA MENURUT HUKUM POSITIF INDONESIA," Jurnal Ilmiah Galuh Justisi 4, no. 1 (March 1, 2016): 27, https://doi.org/10.25157/jigj.v4i1.409.

${ }^{14}$ Azizah, 22 Agustus 2019, Legalitas Tanda Tangan Elektronik Pejabat Dalam Rangka Mendukung EGovernment, https://www.mahkamahagung.go.id/id/artikel/3737/legalitas-tanda-tangan-elektronik-pejabatdalam-rangka-mendukung-e-government cited 15 June 2020
} 


\section{Electronic Medical Records as Evidence in Court}

Beberapa kasus yang terjadi dirumah sakit yang sudah menjalankan rekam medis elektronik, belum ada rekam medis eletronik langsung dijadikan sebagai alat bukti, yang menjadi alat bukti adalah hasil cetak dari dokumen elektronik. Luasnya cakupan alat bukti elektronik, membutuhkan waktu yang lama dan biaya yang tidak sedikit dalam pengumpulan dan pemeriksaannya. ${ }^{15}$

Berikut ini adalah identifikasi penulis terhadap dasar hokum yang digunakan untuk melihat kedudukan dari alat bukti rekam medis sebagai alat bukti;

Table 1. Legal basis for electronic medical records as evidence

\begin{tabular}{|c|c|c|}
\hline NO & Electronic Medical Records & Legal Grounds \\
\hline 1. & $\begin{array}{l}\text { Valid evidence is: } \\
\text { a) Witness statements } \\
\text { b) Experts statements } \\
\text { c) Letter } \\
\text { d) Guidance } \\
\text { e) Statement of the Defendant }{ }^{16}\end{array}$ & Article 184 Criminal Code \\
\hline 2. & $\begin{array}{l}\text { Medical records can be used and submitted as } \\
\text { evidence by the district court in the event of a } \\
\text { medical dispute. During treatment, the patient's } \\
\text { history can be known in the medical record and } \\
\text { evidence that the patient is adequately hospitalized. }{ }^{17}\end{array}$ & $\begin{array}{l}\text { Article } 14 \text { of the Ministry of } \\
\text { Health Regulation } 269 \text { of } 2008\end{array}$ \\
\hline 3. & $\begin{array}{l}\text { As evidence, the medical record must be explained } \\
\text { by a witness who can provide testimony under oath } \\
\text { regarding the origin and what is written in the } \\
\text { medical record. } .^{18}\end{array}$ & $\begin{array}{l}\text { Article } 184 \text { of the Criminal } \\
\text { Code, evidence of expert } \\
\text { testimony }\end{array}$ \\
\hline 4. & $\begin{array}{l}\text { In the case of granting an identity, time and } \\
\text { signature, and initials for changes that are not in the } \\
\text { original writing, written evidence, or letters, in this } \\
\text { case, the electronic medical record, are deemed } \\
\text { ineligible. }{ }^{19}\end{array}$ & $\begin{array}{l}\text { Article } 5 \text { of the Ministry of } \\
\text { Health Regulation No. } 269 \text { of } \\
2008 .\end{array}$ \\
\hline 5. & $\begin{array}{l}\text { In deciding a case, the judge must consider the legal } \\
\text { requirements of the evidence. The judge must look } \\
\text { directly at the strength of evidence between one } \\
\text { evidence and another, whether there is suitability or }\end{array}$ & $\begin{array}{l}\text { Article } 197 \text { paragraph (1) point } \\
\text { d Criminal Procedure Law. }\end{array}$ \\
\hline
\end{tabular}

\footnotetext{
${ }^{15}$ Pandoe Pramoe Kartika, "Data Elektronik Sebagai Alat Bukti Yang Sah Dalam Pembuktian Tindak Pidana Pencucian Uang," Indonesian Journal of Criminal Law 1, no. 1 (May 24, 2019): 33-46, https://doi.org/10.31960/ijocl.v1i1.146.

${ }^{16}$ Nabil Atta Samandari, Wila Chandrawila S, and Agus H. Rahim, "KEKUATAN PEMBUKTIAN REKAM MEDIS KONVENSIONAL DAN ELEKTRONIK," SOEPRA 2, no. 2 (January 10, 2017): 154, https://doi.org/10.24167/shk.v2i2.818.

${ }^{17}$ Soni Praja Manurung, Ismail Ismail, and Salim Fauzi Lubis, "PENGATURAN HUKUM REKAM MEDIS SEBAGAI ALAT BUKTI DI PERSIDANGAN," JURNAL PIONIR 5, no. 4 (November 22, 2019), http://www.jurnal.una.ac.id/index.php/pionir/article/view/914.

${ }^{18}$ Geraldo Angelo Luntungan, "SURAT SEBAGAI ALAT BUKTI MENURUT KITAB UNDANG-UNDANG HUKUM ACARA PIDANA," LEX CRIMEN, vol. 7, July 26, 2018, https://ejournal.unsrat.ac.id/index.php/lexcrimen/article/view/20542.

${ }^{19}$ Nabil Atta Samandari, Loc.Cit
} 


\begin{tabular}{|c|c|c|}
\hline & $\begin{array}{l}\text { not, without neglecting the facts at trial, so that the } \\
\text { judge can decide the case by law, which exists. }{ }^{20}\end{array}$ & \\
\hline 6. & $\begin{array}{l}\text { Parties who want to make electronic documents as } \\
\text { valid evidence if the electronic signatures are } \\
\text { certified. }{ }^{21}\end{array}$ & $\begin{array}{l}\text { Article } 51 \text { of Government } \\
\text { Regulation Number } 71 \text { of } 2019 \\
\text { concerning PSRE in lieu of } \\
\text { Government Regulation } \\
\text { Number } 12 \text { of } 2012\end{array}$ \\
\hline 7. & $\begin{array}{l}\text { There are several cases where an uncertified } \\
\text { electronic signature cannot be used as evidence. If an } \\
\text { organization carries out an electronic signature, the } \\
\text { certification organizing body must be legal. Outside } \\
\text { the six agencies, the Ministry of Communication and } \\
\text { Information has not yet acknowledged them. The } \\
\text { purpose of establishing the Electronic Certification } \\
\text { Operator is to minimize the falsification of electronic } \\
\text { documents. }^{22}\end{array}$ & $\begin{array}{l}\text { Article } 42 \text { Government } \\
\text { Regulation Number } 71 \text { of } 2019 \\
\text { concerning PSRE in lieu of } \\
\text { Government Regulation } \\
\text { Number } 12 \text { of } 2012\end{array}$ \\
\hline
\end{tabular}

Based on the data table above, it can be seen that the position of electronic medical records as evidence is valid under The Ministry of Health Regulation 269 Article 13, which regulates that medical records are one of the evidence used to prove if there is a medical dispute case. Therefore, in dealing with patients, every doctor and dentist must record or write down medical records by including their identity, date, time, and initials/signature.

Printed electronic medical records can be accepted as evidence because they meet the elements following Article 184 paragraph (1) part c of the Criminal Code, namely in the form of letters. If you look at Article 187 of the Criminal Procedure Code, which begins with the sentence "The letter as referred to in Article 184 paragraph (1) letter c, is made on an oath of office or strengthened by an oath." Printed electronic medical records can be accepted as evidence because they meet the elements following Article 184 paragraph (1) part c of the Criminal Code, namely in the form of letters. If you look at Article 187 of the Criminal Procedure Code, which begins with the sentence". As referred to in Article 184 paragraph (1) letter c, the letter is made on an oath of office or strengthened by an oath.

The law that regulates electronic evidence is the ITE Law which states that any electronic evidence can be used as evidence if it meets formal and material requirements, the formal requirements in question are Information or Electronic Documents are not documents or letters in writing, regulated in Article 5 paragraph (4) of the ITE Law. Whereas what is meant by material requirements is that the Electronic Documents displayed must be guaranteed to be accurate, their integrity, and can be available at any time when needed. To ensure the fulfillment of the material requirements referred to, digital forensics is needed in many cases. As evidence, electronic medical records do not have binding evidentiary power but rather have independent evidentiary value, namely, proof determined by the judge's conviction without being limited by law. This is following Article 197 paragraph (1) of the Criminal Code. Proof of authentication in organizing electronic medical records can be in the form of an electronic signature. The electronic signature used is an electronic certificate issued by a certification body recognized by the Ministry of Communication and Information as outlined in Article 42 Government Regulation Number 71. On this basis, some parties claim that if the

\footnotetext{
${ }^{20}$ I. Rusyadi, "KEKUATAN ALAT BUKTI DALAM PERSIDANGAN PERKARA PIDANA," Jurnal Hukum PRIORIS, vol. 5, February 13, 2016, https://trijurnal.lemlit.trisakti.ac.id/prioris/article/view/558.

${ }^{21}$ Results of interviews with Mr. Rynaldy, Head of the Electronic Certification Agency

${ }^{22}$ Results of interviews with the Head of BSE BSSN.
} 
electronic signature is not certified, the electronic document cannot be used as a tool. ${ }^{23}$ With the complexity of implementing the hospital's electronic system, especially regarding authentication, the hospital can manage internal policies in the hospital bylaws and medical staff by law. The consideration of internal policies' use relates to the number of professional carer signatures (PPA) that must be registered and the costs incurred. The PPA is a doctor/dentist, nurse, pharmacist, dietitian involved in inpatient care.

Judicial institutions have an essential role in accepting, adjudicating, and deciding cases, both criminal and civil. ${ }^{24}$ One of the functions of the theory of proof is the descriptive function, which can explain existing phenomena. For example, it is proof of electronic documents. ${ }^{25}$ According to the Criminal Procedure Code, the proof system adopted in Indonesia is negative evidence (negative wettelijk stelsel). If there are at least two valid pieces of evidence, a judge may impose a sentence on a person if he or she is convinced that the defendant has committed a crime. Even though the documentary evidence is not the main one, it is still interested in the proof. ${ }^{26}$ According to the Civil Code, legal evidence includes written evidence, evidence with witnesses, allegations, confessions, and oaths. The fundamental difference between evidence in civil and criminal cases lies not in the testimony, which is the primary evidence, but in written or letter evidence. The authentic deed and the deed underhand constitute written evidence other than the letter as referred to in the provisions of the Civil and Criminal Procedure Law. ${ }^{27}$ The power of proof that has three types of evidentiary power is an authentic deed ${ }^{28}$ namely the power of external proof, the power of formal proof, and material evidence. ${ }^{29}$ Regarding the proof of a letter as evidence that is not regulated by law, the power of proof is left to the judge's consideration. This is following Article 1867 of the Civil Code. ${ }^{30}$

As a valid indication, a letter is one of several types of evidence in criminal procedural law. On written evidence or letters, the most crucial part is the signature. By putting a signature, the parties are responsible for the content and correctness are written on the signature. ${ }^{31}$ The task of law enforcers is to assess signatures that apply to electronic documents used as evidence in court. According to the ITE Law, electronic documents can be used as other evidence that is following the laws and regulations in the process of examination and litigation in court proceedings. ${ }^{32}$ With these provisions, electronic evidence can be accepted in the judicial system in Indonesia. The power of proof is non-binding and free. The judge has the right to evaluate all the evidence used as proof. ${ }^{33}$ The development of a civilproof system is one of the impacts associated with electronic evidence. The burden of proof lies with the public prosecutor at trial because proof of the defendant's negligence must be

\footnotetext{
${ }^{23}$ Results of interviews with the Head of BSE BSSN

${ }^{24}$ Salim HS, 2016, Penerapan Teori Hukum Pada Penelitian Disertasi dan Tesis, Rajawali Pers, Depok, Cetakan 1, pg 215

25 Richard Cisanto Palit, "KEKUATAN AKTA DI BAWAH TANGAN SEBAGAI ALAT BUKTI DI PENGADILAN,” LEX PRIVATUM, vol. $\quad 3, \quad$ May $\quad 4, \quad 2015$, https://ejournal.unsrat.ac.id/index.php/lexprivatum/article/view/7842.

${ }^{26}$ Nabil Atta Samandari, Loc. Cit.

${ }^{27}$ Darus Harizona, "Kekuatan Bukti Elektronik Sebagai Bukti Di Pengadilan Menurut Hukum Acara Pidana Dan Hukum Islam (Penggunaan Rekaman Gambar Closed Circuit Television)," Jurnal Intelektualita: Keislaman, Sosial Dan Sains 7, no. 1 (July 10, 2018): 81-98, https://doi.org/10.19109/intelektualita.v7i1.2342.

${ }^{28}$ Ibid, pg. 199

${ }^{29}$ R. Subekti, Loc. Cit. 1, pg. 25-30.

${ }^{30}$ R. Soepomo, 2004, Hukum Acara Perdata Pengadilan Negeri, Pradnya Paramita, Jakarta, pg. 82

${ }^{31}$ Op. Cit., pg. 33

${ }^{32}$ Article 44 of Law Number 19 the Year 2016 concerning Electronic Information and Transactions

${ }^{33}$ Koespramono, Loc. Cit
} 
rational and not doubtful. ${ }^{34}$ Suppose there is a lack of written evidence to prove the case at trial regarding the accused's guilt. In that case, the advantage of the public prosecutor's doubt has implications for the obligation to release the defendant from all charges (in dubio proreo). The proof is acceptable for a crime because insufficient evidence is not a guarantee to accuse a defendant as the basis for an unclear and dubious testimony. ${ }^{35}$

In seeking the truth and legal certainty of a case based on the plaintiff's petition, evidence and evidence are very important in civil procedural law. This occurs when law enforcement officers have difficulty seeking civil rights for the parties if no governing law is found. The benefits obtained by law enforcement officials from the passing of the ITE Law are expected to prevent acts that violate the law. ${ }^{36}$ This occurs when law enforcement officers have difficulty seeking civil rights for the parties if no governing law is found. The benefits obtained by law enforcement officials from the passing of the ITE Law are expected to prevent acts that violate the law. Electronic documents that are printed and affixed with a wet signature have become valid evidence in both the Criminal Procedure Code and Civil Procedure Law, namely documentary evidence. If the electronic document is not printed, but in court, the document is read and explained by an expert, it is classified as expert testimony. ${ }^{37}$

In principle, Electronic Information is part of Electronic Documents. If Electronic Information is a collection of data, then Electronic Documents is a place for Electronic Information. According to the law, electronic evidence, which is valid according to Article 5 paragraph (1) of the ITE Law, is Electronic Information and/or Electronic Documents and their printouts. Several requirements for electronic evidence can be considered as evidence. Digital signatures are considered original, guaranteeing that the document's contents are original, intact and unchanging. ${ }^{38}$

Of the several cases in hospitals that have run electronic medical records, there is no electronic medical record that is directly used as evidence, which becomes evidence is printed results of electronic documents. If the formal and material requirements are met on electronic evidence, it can be used as evidence. ${ }^{39}$ As evidence, electronic medical records do not have binding evidentiary power but rather have independent evidentiary value, namely, proof determined by the judge's conviction without being limited by law.

\section{Administrative Sanction}

According to applicable regulations, as one of the hospital public service institutions, it is required to register the electronic system used, not only the electronic system, the hospital's operating license must always be updated to continue to serve the community. If the hospital does not have an operational permit, then administratively, the services performed are illegal, which implies that all services are administratively invalid. Government Regulation Number 71 of 2019 concerning PSTE requires every electronic system operator to register before the electronic system is used. Registration is carried out through a licensing service, but the

\footnotetext{
34 Efa Laela Fakhriah, "PERKEMBANGAN ALAT BUKTI DALAM PENYELESAIAN PERKARA PERDATA DI PENGADILAN MENUJU PEMBARUAN HUKUM ACARA PERDATA,” ADHAPER: Jurnal Hukum Acara Perdata 1, no. 2 (September 16, 2015): 135-153, https://doi.org/10.36913/JHAPER.V1I2.16.

${ }^{35}$ Eddy Rifai Kedudukan Dan Fungsi Hakim Sebagai Penegak Hukum Dan Keadilan (Studi Kasus Putusan Mahkamah Agung R.I. No. 1176 K/Pid/2007) Staf Pengajar Bagian Hukum Pidana Fakultas Hukum Universitas Lampung

${ }^{36}$ Johan Wahyudi Dokumen Elektronik Sebagai Alat Bukti Pada Pembuktian Di Pengadilan Fakultas Hukum Universitas Airlangga Surabaya, 2012

${ }^{37}$ Results of an interview with Ms. Unila Triani, Judge at the Class 1B District Court, Metro Lampung City

${ }^{38}$ Komang Ayu Trisna Cahya Dewi , Kedudukan Alat Bukti Elektronik Dalam Hukum Acara Pidana Indonesia

39 Suzeth Agustien Simbolon, "KAJIAN YURIDIS TERHADAP KEDUDUKAN REKAM MEDIS ELEKTRONIK DALAM PEMBUKTIAN PERKARA PIDANA MALPRAKTEK OLEH DOKTER,” LEX CRIMEN, vol. 4, November 3, 2015, https://ejournal.unsrat.ac.id/index.php/lexcrimen/article/view/9803.
} 
regulation does not provide sanctions if the electronic system operator does not register the system used. Regulation of the Minister of Communication and Information Number 36 of 2014 concerning Electronic System Operator Registration Procedures-only regulates the registration method only, and there are no sanctions if the regulation is not implemented. Licensing violations can be stipulated as administrative sanctions, which are generally included in the implementation of the basis of legislation. ${ }^{40}$

Administrative law enforcement is the authority of the Government. The instruments used are supervision and administrative sanctions. Supervision is a means to prevent violations from occurring, while administrative sanctions are an instrument in preventing or stopping violations and recovering the consequences of these violations. ${ }^{41}$ In terms of their nature, administrative sanctions can be divided into restoration or corrective sanctions and punitive sanctions. Restoration sanctions aim to restore the lawful state to the way it was before the violation occurred. The important thing that must be considered in imposing coercive government sanctions or other types of administrative sanctions must be based on strict provisions in the laws and regulations that give the authority to do so (legality principle). ${ }^{42}$ In conducting electronic transactions, the hospital should be obliged to register the electronic system used. Obligation to Operate Electronic Systems to have electronic certificates. The electronic certificate serves as the identity, integrity, and authenticity of electronic information. When used as electronic documents, management of medical record documents requires separate management seen from the hospital leadership policies. Thus, the National Cyber and Crypto Agency or Badan Siber dan Sandi Negara (BSSN), through its Electronic Certification Body or Badan Sertifikasi Elektronik (BSE), does not regulate the substance, where medical records are confidential documents that cannot be accessed because, for electronic certification administrators, data must be sent first to the data center of the electronic certification provider. ${ }^{43}$ This is also the case with the implementation. Although there is no technical guideline for implementing electronic medical records, hospitals can make policies based on applicable laws and regulations in the form of the hospital by laws and medical staff by laws. Other internal regulations are technical guidelines for internal medical records and standard operating procedures so that there are new references for electronic medical record users. There is specificity for administrators of electronic medical records to carry out their functions where the hospital's internal policies can fulfill the administrative system.

\section{Closing \\ 1. Conclusion}

Electronic medical records have an essential role in health services and law enforcement efforts as evidence. Based on the description of the above discussion, it can be concluded that the position of electronic medical records as evidence in court can be valid evidence following; Article 1, Article 5, and Article 184, the Ministry of Health Regulation No. 269 the Year 2008, Article 51 of Government Regulation No. 71 of 2019. As evidence, electronic medical records do not have binding evidentiary power but rather have independent evidentiary value, namely, proof determined by the judge's conviction without being limited by law.

\footnotetext{
${ }^{40}$ Ivan Fauzani Raharja, "PENEGAKAN HUKUM SANKSI ADMINISTRASI TERHADAP PELANGGARAN PERIZINAN," INOVATIF, vol. 7, 2014, https://online-journal.unja.ac.id/jimih/article/view/2064.

${ }^{41}$ A'an Efendi, 2017, Hukum Administrasi, (Sinar Grafika, Jakarta), Pg 303

${ }^{42}$ Ibid, pg 305

${ }^{43}$ Results of interviews with Mr. Rynaldi, Head of the Electronic Certification Agency
} 


\section{BIBLIOGRAPHY}

\section{A. Book}

Boy S. Sabarguna, (2008), Rekam Medis Terkomputerisasi, Jakarta: UI Press.

Josua Sitompul, (2012). Cyberspace, Cybercrime, Cyberlaw, Jakarta: Tatanusa

R. Soepomo, (2004), Hukum Acara Perdata Pengadilan Negeri, Jakarta: Pradnya Paramita.

Salim HS, (2016), Penerapan Teori Hukum Pada Penelitian Disertasi dan Tesis, Depok: Rajawali Pers.

Zaeni Asyhadie, (2017). Aspek-Aspek Hukum Kesehatan Di Indonesia, Depok; Rajawali Pers.

\section{B. Journal}

Fakhriah, Efa Laela. "PERKEMBANGAN ALAT BUKTI DALAM PENYELESAIAN PERKARA PERDATA DI PENGADILAN MENUJU PEMBARUAN HUKUM ACARA PERDATA." ADHAPER: Jurnal Hukum Acara Perdata 1, no. 2 (September 16, 2015): 135-153. https://doi.org/10.36913/JHAPER.V1I2.16.

Harizona, Darus. "Kekuatan Bukti Elektronik Sebagai Bukti Di Pengadilan Menurut Hukum Acara Pidana Dan Hukum Islam (Penggunaan Rekaman Gambar Closed Circuit Television)." Jurnal Intelektualita: Keislaman, Sosial Dan Sains 7, no. 1 (July 10, 2018): 81-98. https://doi.org/10.19109/intelektualita.v7i1.2342.

Juanda, Enju. "KEKUATAN ALAT BUKTI DALAM PERKARA PERDATA MENURUT HUKUM POSITIF INDONESIA.” Jurnal Ilmiah Galuh Justisi 4, no. 1 (March 1, 2016): 27. https://doi.org/10.25157/jigj.v4i1.409.

Kartika, Pandoe Pramoe. "Data Elektronik Sebagai Alat Bukti Yang Sah Dalam Pembuktian Tindak Pidana Pencucian Uang.” Indonesian Journal of Criminal Law 1, no. 1 (May 24, 2019): 33-46. https://doi.org/10.31960/ijocl.v1i1.146.

Luntungan, Geraldo Angelo. "SURAT SEBAGAI ALAT BUKTI MENURUT KITAB UNDANG-UNDANG HUKUM ACARA PIDANA." LEX CRIMEN. Vol. 7, July 26, 2018. https://ejournal.unsrat.ac.id/index.php/lexcrimen/article/view/20542.

Manurung, Soni Praja, Ismail Ismail, and Salim Fauzi Lubis. "PENGATURAN HUKUM REKAM MEDIS SEBAGAI ALAT BUKTI DI PERSIDANGAN.” JURNAL PIONIR 5, $\begin{array}{llll}\text { no. } & \text { (November 2019). }\end{array}$ http://www.jurnal.una.ac.id/index.php/pionir/article/view/914.

Murniati, Lucia, Endang Wahyati Y, and Siswo Putranto Santoso. "IMPLEMENTASI HOSPITAL BYLAWS DI RUMAH SAKIT SANTO ANTONIO BATURAJA SETELAH BERLAKUNYA PERMENKES NOMOR: 755/MenKes/Per/IV/2011 TENTANG PENYELENGGARAAN KOMITE MEDIK DI RUMAH SAKIT." SOEPRA 2, no. 2 (January 10, 2017): 143. https://doi.org/10.24167/shk.v2i2.817.

Octarina, Nynda Fatmawati, Muh. Barid Nizaruddin Wajdi, M. Ikhsan Setiawan, Agus Sukoco, Tubagus Purworusmiardi, and Nuning Kurniasih. "Tinjauan Terhadap UU ITE Untuk Penerapan Rekam Medis Berbasis Online Pada Penduduk Muslim Di Indonesia." At-Tahdzib: Jurnal Studi Islam Dan Muamalah 5, no. 2 (2017): 78-94. http://ejournal.kopertais4.or.id/mataraman/index.php/tahdzib/article/view/3253.

Palit, Richard Cisanto. "KEKUATAN AKTA DI BAWAH TANGAN SEBAGAI ALAT BUKTI DI PENGADILAN." LEX PRIVATUM. Vol. 3, May 4, 2015. https://ejournal.unsrat.ac.id/index.php/lexprivatum/article/view/7842.

Raharja, Ivan Fauzani. "PENEGAKAN HUKUM SANKSI ADMINISTRASI TERHADAP PELANGGARAN PERIZINAN.” INOVATIF. Vol. 7, 2014. https://online- 
journal.unja.ac.id/jimih/article/view/2064.

Rusyadi, I. "KEKUATAN ALAT BUKTI DALAM PERSIDANGAN PERKARA PIDANA."

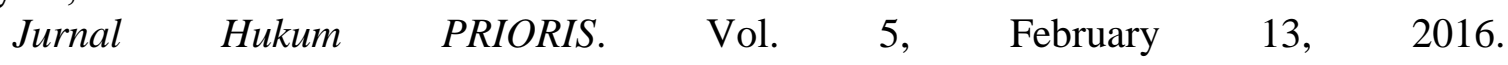
https://trijurnal.lemlit.trisakti.ac.id/prioris/article/view/558.

Samandari, Nabil Atta, Wila Chandrawila S, and Agus H. Rahim. "KEKUATAN PEMBUKTIAN REKAM MEDIS KONVENSIONAL DAN ELEKTRONIK." SOEPRA 2, no. 2 (January 10, 2017): 154. https://doi.org/10.24167/shk.v2i2.818.

Simbolon, Suzeth Agustien. "KAJIAN YURIDIS TERHADAP KEDUDUKAN REKAM MEDIS ELEKTRONIK DALAM PEMBUKTIAN PERKARA PIDANA MALPRAKTEK OLEH DOKTER.” LEX CRIMEN. Vol. 4, November 3, 2015. https://ejournal.unsrat.ac.id/index.php/lexcrimen/article/view/9803.

Sudjana, Sudjana. "Aspek Hukum Rekam Medis Atau Rekam Medis Elektronik Sebagai Alat Bukti Dalam Transaksi Teurapetik." Veritas et Justitia 3, no. 2 (December 26, 2017): 359-83. https://doi.org/10.25123/vej.2685.

Wahyudi, Johan. "DOKUMEN ELEKTRONIK SEBAGAI ALAT BUKTI PADA PEMBUKTIAN DI PENGADILAN.” Perspektif 17, no. 2 (May 27, 2012): 118-26. http://jurnal-perspektif.org/index.php/perspektif/article/view/101. 
